\title{
Protein metabolism during lactation
}

\author{
BY NEIL S. JESSOP \\ Institute of Ecology and Resource Management, The University of Edinburgh, Kings Buildings, \\ West Mains Road, Edinburgh EH9 $3 J G$
}

Lactation increases considerably the demand for amino acids over that required for basal needs. The demand imposed varies with the quantity of milk produced and, between species, with the protein content of milk. Using data on milk composition from Blaxter (1989) and assuming milk production of 60,1000 and $50000 \mathrm{ml} / \mathrm{d}$ for a rat, human subject and dairy cow respectively, the ideal protein required can be calculated as 5.7, 32 and $1465 \mathrm{~g} / \mathrm{d}$. (This calculation assumes the efficiency of use of the first limiting amino acid to be 0.85 ; Oldham, 1987). If this is expressed relative to the minimal requirement for amino acids, it gives a measure of the relative cost of lactation to the animal. Maintenance needs for amino acids can be considered to arise from obligatory losses occurring within the body (such as catabolism of amino acids, skin and hair loss) and those associated with protein loss to the gut. The latter varies with intake and, hence, dietary characteristics and has been estimated to account for $60 \%$ of maintenance needs (Moughan, 1989). Thus, minimal requirements can be estimated as $40 \%$ of maintenance needs, calculated from Emmans \& Oldham (1988). The relative amino acid cost of lactation for the rat, human subject and dairy cow, when producing the daily quantities of milk given previously are thus 11.0, 1.4 and $12 \cdot 1$ respectively. The cost for the rat and high-producing dairy cow are somewhat similar and substantially higher than that for human subjects.

\section{CAN SUCH ELEVATED REQUIREMENTS BE MET FROM DIETARY SUPPLY?}

Many studies have been conducted in our laboratories to determine the response of lactating rats to changes in the nutrient balance of the diet. We chose the rat as an experimental model as it has a substantially-elevated nutrient requirement during lactation and its digestive anatomy makes it easier to predict nutrient supply from the diet when compared with a ruminant. Intake varies markedly with the protein content of the diet such that DM intake is reduced at lower protein contents (Fig. 1(a)). Our early work identified a threshold protein content of the diet below which the intakes of females were too low to support lactation (Friggens et al. 1993) and our subsequent studies have concentrated on diets in which the crude protein $(\mathrm{N} \times 6.25 ; \mathrm{CP})$ content is varied between 210 and $90 \mathrm{~g} / \mathrm{kg}$ DM by substitution with a mixture of fat and carbohydrate such that all diets are isoenergetic. A consequence of reduced intake during lactation is reduced lactational performance (as measured by the growth rate of a litter of twelve pups) and an increase in the rate of body-weight loss (Fig. 1). Thus, as amino acid supply from the diet is reduced through changes in intake and diet composition, so there is an increase in use of endogenous nutrients, body protein and fat.

\section{TO WHAT EXTENT CAN ENDOGENOUS PROTEIN COMPENSATE FOR REDUCED DIETARY SUPPLY?}

Pine et al. (1994a) describe an experiment in which the protein content of female rats at the start of lactation was varied by dietary means, and their response to dietary protein supply during lactation was studied. The biphasic nature of protein metabolism during gestation 

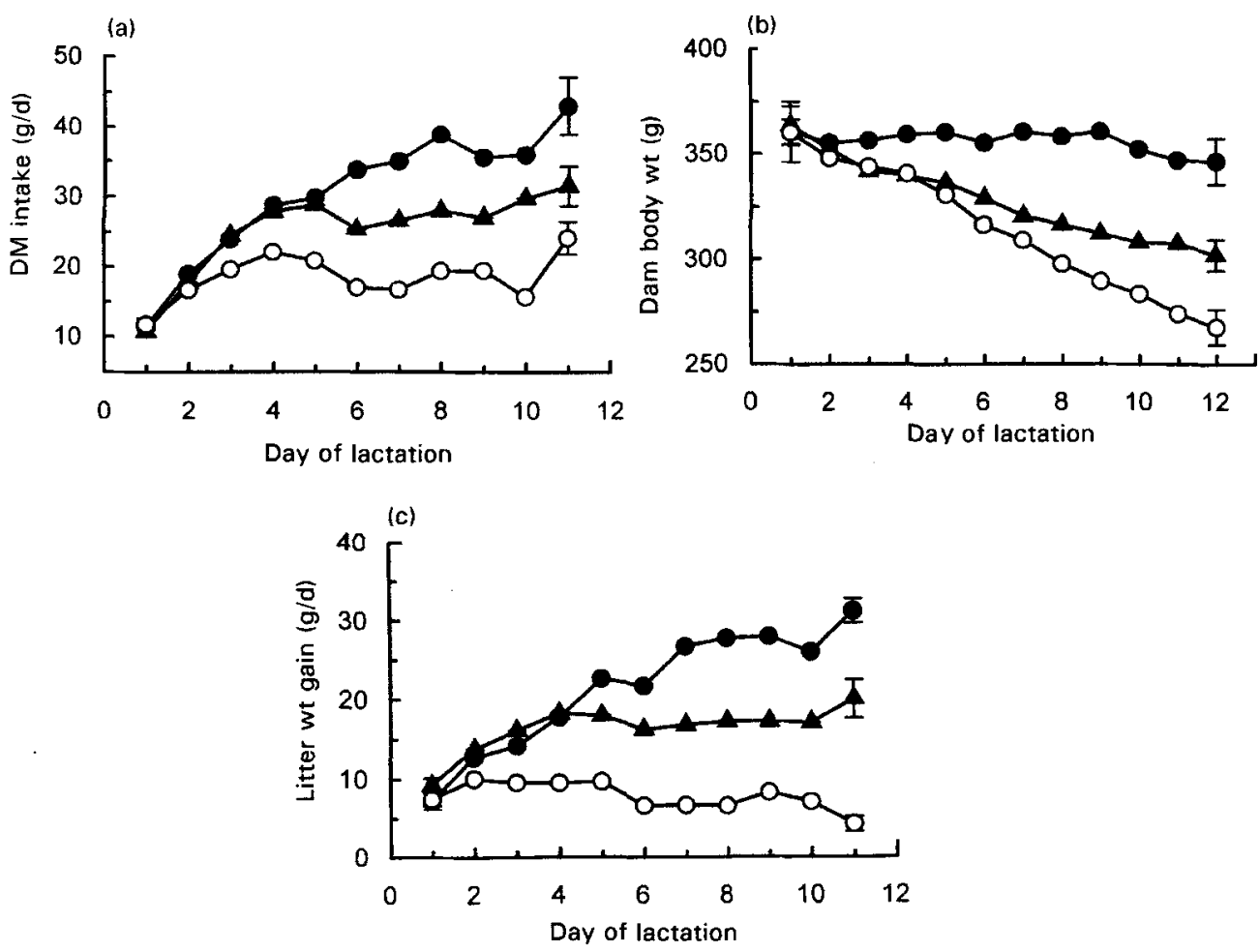

Fig. 1. The effect of dietary protein content on (a) DM intake ( $\mathrm{g} / \mathrm{d})$, (b) body-weight change (g), and (c) lactational performance, as measured by the gain in weight $(\mathrm{g})$ of a litter of twelve rat pups. Groups of females received diets containing either $210(\Theta), 150(\Delta)$ or $90(O) \mathrm{g}$ crude protein $(\mathrm{N} \times 6.25) / \mathrm{kg}$ DM from parturition. Values are means with their standard errors represented by vertical bars.

(Naismith \& Morgan, 1976) was used to vary maternal protein levels without affecting litter weight or pup numbers. All animals were given access to a diet containing $210 \mathrm{~g} \mathrm{CP} /$ $\mathrm{kg} \mathrm{DM}$ for the first half of gestation to allow for establishment of pregnancy and placental development. At this time, half the females were transferred to a low-protein diet (whilst the other half remained on the high-protein diet) to increase endogenous protein loss. At parturition, half the females from each group were given access to a high-protein diet and half to a low-protein diet. Carcass protein at parturition was reduced by feeding of the lowprotein diet during the latter half of gestation. Gestational treatment had no effect on intakes and performance during lactation for those animals receiving a high-protein diet. For those given a low-protein diet during lactation, those animals with higher body protein contents lost more protein during lactation, had higher DM intakes and had a greater lactational performance when compared with those that started lactation with a lower body protein content (Fig. 2). By the 13th day of lactation (the end of the experiment), the protein contents of both groups of females given the low-protein diet during lactation were similar and the maximum amount of body protein lost was approximately $250 \mathrm{~g} / \mathrm{kg}$. The pattern of loss over this time was subsequently shown not to be linear (Pine et al. 1994c), with the highest rates of loss occurring during the first $4 \mathrm{~d}$ of lactation, based on measurements of protein loss from the gastrocnemius muscle. Measured rates of protein synthesis and calculated rates of protein degradation showed little change in the former, but 


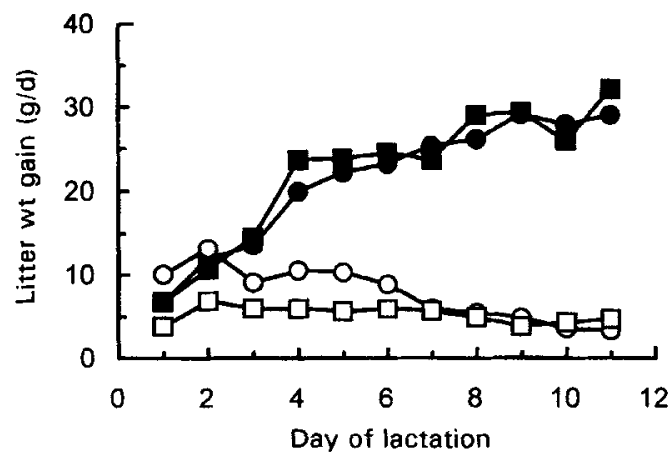

Fig. 2. Lactational performance, as measured by the increase in weight $(\mathrm{g})$ of litters of twelve rat pups, of rats offered either a diet containing $210 \mathrm{~g}$ crude protein $(\mathrm{N} \times 6.25 ; \mathrm{CP}) / \mathrm{kg} \mathrm{DM}(\mathrm{H}-)$ or a diet containing $60 \mathrm{~g} \mathrm{CP} / \mathrm{kg}$ DM (L-) for the last half of gestation followed by diet $\mathrm{H}(-\mathrm{H})$ or a diet containing $90 \mathrm{~g} \mathrm{CP} / \mathrm{kg} \mathrm{DM}(-\mathrm{L})$ during lactation: (O) $\mathrm{HH}$; ( $\square$ ) $\mathrm{HL} ;(\mathbf{G}) \mathrm{LH} ;(\mathrm{O}) \mathrm{LL}$.

large changes in the latter. The fractional rate of degradation was calculated to be $0 \cdot 14 / \mathrm{d}$ between days 2 and 4, reducing to 0.04 /d between days 8 and 12. Overall, rates of muscle protein synthesis were $25 \%$ lower in animals receiving the low-protein diet during lactation when compared with those receiving the high-protein diet (Pine et al. 1994b). Studies with human subjects have shown that $\mathrm{N}$ balance during lactation is closely related to the insulin:cortisol value, insulin having an anabolic effect and cortisol a catabolic one (Motil et al. 1994).

During early lactation there is partition of available protein towards certain organs (notably mammary gland and splanchnic tissues) at the expense of carcass protein. This has been shown to be due to an increase in the insulin sensitivity of the mammary gland and liver during early lactation combined with a lower insulin secretion (Girard et al. 1987). Data from Pine et al. $(1994 a, b)$ show that when dietary protein supplies are adequate, there is an increase in the protein content of mammary and splanchnic tissues but not of carcass and an increase in fractional synthetic rate of mammary protein. If dietary protein was low $(90 \mathrm{~g} \mathrm{CP} / \mathrm{kg} \mathrm{DM})$, then protein was lost from all tissues.

The ability to secrete milk depends on the number and activity of mammary cells. In the rat, substantial mammary development takes place following parturition (Knight \& Peaker, 1982) and has been shown to be dependent on diet quality (Goodwill et al. 1996a). Whether this pattern of development post-parturition occurs in other species is less clear since most studies have involved measuring mammary gland mass rather than an index of cell number (such as DNA content). The study of Goodwill et al. (1996a) shows that there can be large changes in mammary-gland weight due to fat loss without changes in cell number.

The potential contribution of endogenous protein to lactation can be calculated assuming that $250 \mathrm{~g} / \mathrm{kg}$ body protein can be lost (Allison \& Wannemacher, 1965; Botts et al. 1979; Pine et al. 1994a). This gives a potential protein supply of 13,2250 and $22500 \mathrm{~g}$ for the rat, human subject and dairy cow respectively, equivalent to a milk yield of 140 , 225000 and $550000 \mathrm{ml}$ respectively for these species (using milk composition from Blaxter, 1989). This is equivalent to $2.3,225$ and $11 \mathrm{~d}$ production respectively and shows, for the human subject, the potential significance of endogenous reserves.

Of interest from these studies was the magnitude of the effect of endogenous protein use on intake and lactational performance. Theoretical considerations predict a greater effect than was observed. In all studies from this laboratory, covering a wide range of diet 

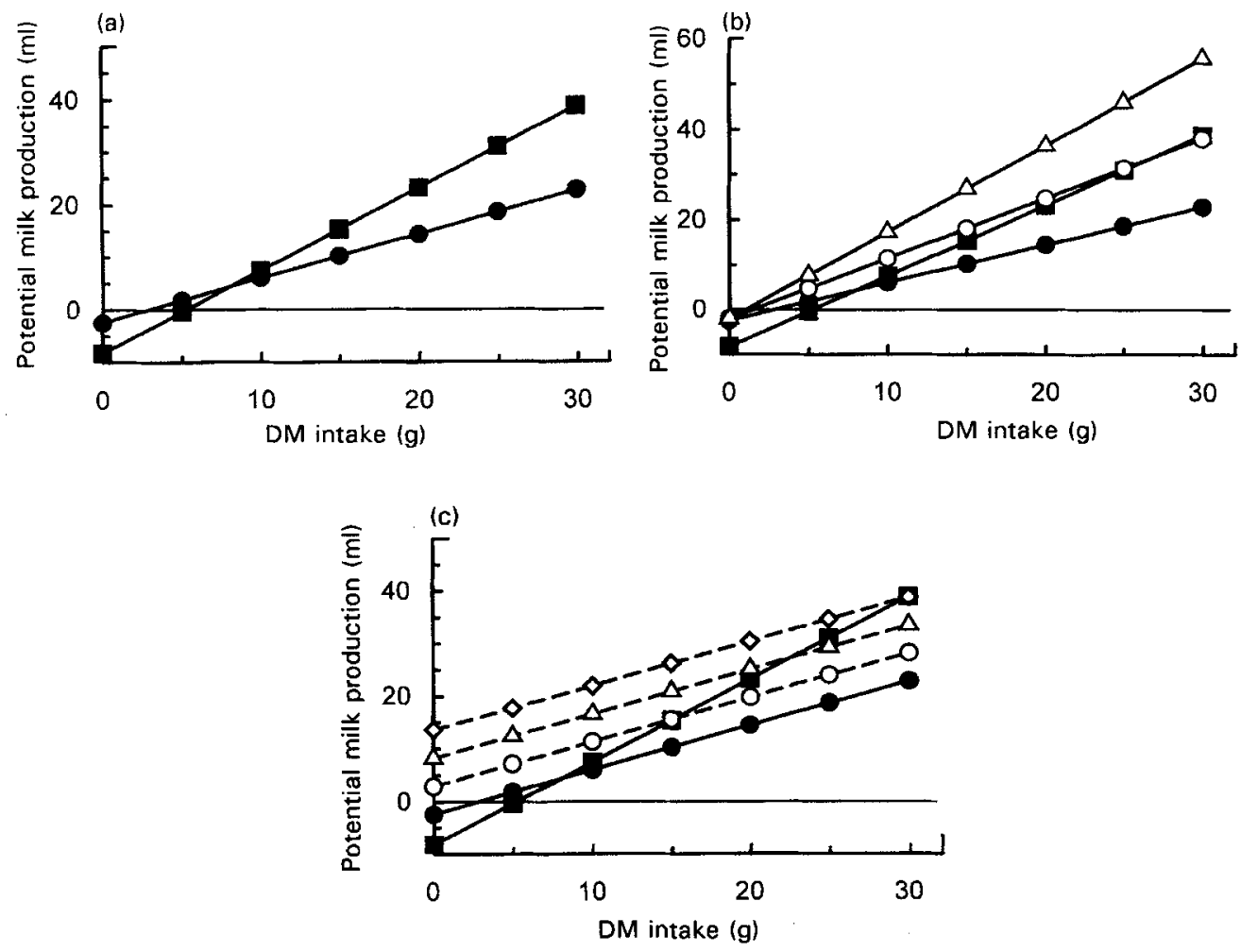

Fig. 3. Potential milk production, over a range of DM intakes, of lactating rats limited by supply of dietary plus endogenous energy $(\mathbf{G})$ and the supply of dietary protein $(O)$ for (a) a diet containing $90 \mathrm{~g}$ crude protein $(\mathrm{N} \times 6.25$; $\mathrm{CP}) / \mathrm{kg} \mathrm{DM}$, (b) diets containing $90(0), 150(\mathrm{O})$ and $210(\triangle) \mathrm{g} \mathrm{CP} / \mathrm{kg} \mathrm{DM}$, and (c) a diet containing $90 \mathrm{~g} \mathrm{CP} / \mathrm{kg} \mathrm{DM}$ with rates of endogenous protein loss of $0(\Theta), 0.5(O), 1.0(\triangle)$ and $1.5(\circlearrowleft) \mathrm{g} / \mathrm{d}$.

compositions, female rats have never been observed to increase their fat mass during early lactation; they all lose between 20 and $60 \mathrm{~g}$. Other studies have shown that the hormonal environment prevalent during early lactation results in a reduction in the capability of adipose tissue to synthesize lipid but not in rates of lipid loss (Marinchenko et al. 1992), resulting in a net loss of lipid from adipose tissue. This imposes a constraint on intake such that an animal is not able to store excess dietary energy as body lipid and, thus, would have to restrict intake to the level at which all energy could be used for maintenance and lactation. This can be seen from Fig. 3(a), which shows, for a particular diet (in this case, a diet containing $90 \mathrm{~g} \mathrm{CP} / \mathrm{kg} \mathrm{DM}$ ), the potential of the rat to synthesize milk from both the protein and energy intakes as DM intake increases. The assumptions used in the calculations were: (a) maintenance energy costs were calculated from Emmans \& Oldham (1988), assuming a mature protein mass of $70 \mathrm{~g}$, (b) endogenous loss of lipid was $2 \mathrm{~g}$ (Pine et al. 1994a), (c) the combined digestive and metabolic efficiency of dietary energy was 0.85 , (d) efficiency of use of first-limiting amino acid was 0.85 (Oldham, 1987), (e) loss of amino acid from gut increases with DM intake following Butts et al. (1993). In Fig. 3(a) the two lines, representing potential milk production from energy and from protein supply, intersect at a DM intake of $8 \mathrm{~g} / \mathrm{d}$. At intakes below $8 \mathrm{~g} / \mathrm{d}$ the supply of energy would limit milk production, whilst at intakes above this the supply of amino acids would be the limiting factor. If supply of amino acids limits milk production, there is, therefore, an 
Table 1. Observed and predicted intakes at two points in lactation for rats offered a diet during lactation containing $90 \mathrm{~g}$ crude protein $(N \times 6.25) / \mathrm{kg} D M$ with or without dietary protein restriction during gestation

\begin{tabular}{cccc}
\hline & & \multicolumn{2}{c}{ DM intake (g/d) } \\
\cline { 3 - 4 } Treatment & Stage of lactation & Observed & Predicted \\
\hline Low-protein diet during gestation & Early (day 4) & 10 & 22 \\
High-protein diet during gestation & Mid (day 8) & 8 & 8 \\
& Early (day 4) & 20 & 30 \\
& Mid (day 8) & 10 & 8 \\
\hline
\end{tabular}

excess of energy which, for reasons given earlier, the animal cannot tolerate. Thus, the point of intersection of these two lines is the predicted maximum intake for that animal. Fig. 3(b) shows how this varies as the protein content of the diet increases. For an animal consuming a diet containing $150 \mathrm{~g} \mathrm{CP} / \mathrm{kg} \mathrm{DM}$, the point of intersection is $27 \mathrm{~g} \mathrm{DM} / \mathrm{d}$, whilst for a diet with $210 \mathrm{~g} \mathrm{CP} / \mathrm{kg} \mathrm{DM}$, the lines do not intersect and it is predicted that there would not be a nutritional constraint on intake. (It has been proposed that, on this diet, intake is determined by nutrient demand in early lactation and limited by heat stress from day 6; Jessop, 1996.) Fig. 3(c) shows the effect of endogenous protein loss on potential milk production from a diet containing $90 \mathrm{~g} \mathrm{CP} / \mathrm{kg} \mathrm{DM}$. As the rate of endogenous protein loss increases, so the point of intersection increases to a higher DM intake.

Comparison of such predicted intakes with those observed is given for two points in lactation in Table 1. From the pattern and extent of endogenous protein loss (Pine et al. $1994 a, c)$, it can be calculated that those animals that were protein restricted during the latter half of gestation would lose $1 \mathrm{~g} \mathrm{CP} / \mathrm{d}$ in early lactation, whilst those that were not protein restricted during gestation would lose $1.5 \mathrm{~g} \mathrm{CP} / \mathrm{d}$. For both groups, the rate of endogenous protein loss in mid lactation (day 8 ) would be very low and is assumed to be zero. Predicted intakes are substantially higher than observed in early lactation, but agree well in mid lactation.

\section{ENDOGENOUS PROTEIN LOSS AND VOLUNTARY INTAKE}

Kyriazakis et al. (1990) showed that as the protein content of a diet reduced below optimal levels, one response of the animal was to increase its total intake. This was presumably to maintain total protein intake at the expense of increased energy intake, with one consequence being an increased rate of fat deposition. If the ideal protein content of the diet is reduced to extremely low levels, then a marked reduction in food intake is observed. It has been proposed that it is the mobilization of body protein to meet the maintenance amino acid requirement of the animal that causes the reduction in intake (Mercer et al. 1994). The types of protein lost, haemoglobin and muscle carnosine, contain relatively high levels of histidine. Together with the reduction in hepatic histidase (EC 4.3.1.3) activity seen during periods of net body protein loss, this results in an elevation of plasma histidine relative to other amino acids. Histidine crosses the blood-brain barrier and is converted into histamine which acts through binding to receptors in the hypothalamus to reduce voluntary intake. When young rats, given access to diets with very low levels (less than $40 \mathrm{~g} / \mathrm{kg} \mathrm{DM}$ ) of ideal protein, were injected with cyproheptadine, a drug which competitively inhibits binding of histamine to its receptors, voluntary intake was markedly increased relative to control rats injected with saline $(9 \mathrm{~g} \mathrm{NaCl} / \mathrm{l}$; Mercer et al. 1989). 


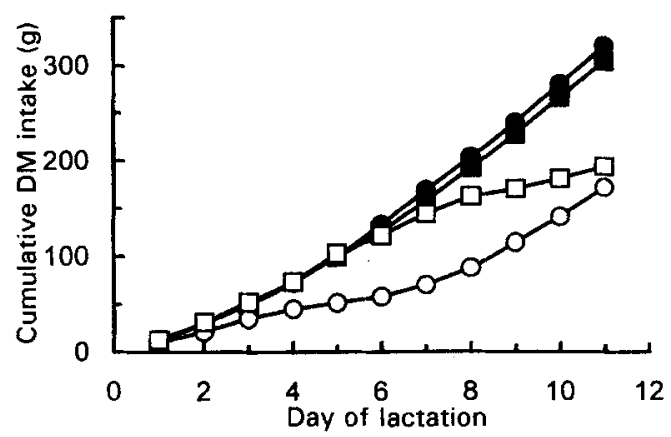

Fig. 4. Cumulative DM intake (g) of lactating rat dams offered either a diet containing $210 \mathrm{~g}$ crude protein $(\mathrm{N} \times 6.25$; $\mathrm{CP}) / \mathrm{kg} \mathrm{DM}(\mathrm{H}-)$ or one containing $90 \mathrm{~g} \mathrm{CP} / \mathrm{kg} \mathrm{DM}(\mathrm{L}-)$, injected daily with either physiological saline $(9 \mathrm{~g} \mathrm{NaCl} / \mathrm{l} ;-\mathrm{S})$ or cyproheptadine (-D): (๑) HS; (ロ) HD; (O) LS; ( $\square$ ) LD.

We investigated whether this mechanism was responsible for the apparently low intakes of rats rapidly mobilizing body protein during early lactation. Rats which had not been protein-restricted during gestation were given a diet containing either $210 \mathrm{~g}$ or $90 \mathrm{~g} \mathrm{CP} / \mathrm{kg} \mathrm{DM}$, and injected daily with either cyproheptadine or saline in a $2 \times 2$ factorial design (Goodwill et al. 1996b). Fig. 4 shows that there was no effect of the drug on intake for the animals given the diet with the higher protein content. For animals receiving the diet with the lower protein content, DM intake was higher during early lactation in those animals given the cyproheptadine. In this group, average daily intake reached $30 \mathrm{~g} \mathrm{DM}$, which agrees well with the intake predicted for such animals shown in Table 1. During mid lactation (day 8), when the rate of body protein loss has been shown to be very low (Pine $e t$ al. $1994 c$ ), the intake of the group injected with the drug had dropped to $10 \mathrm{~g} \mathrm{DM} / \mathrm{d}$, very close to that predicted from consideration of protein and energy supply. Lactational performance was increased, although the pattern of body-weight loss, allowing for increased intake, was not.

\section{CONCLUSION}

Lactation increases the requirement for amino acids considerably, although the extent of this varies widely between species. Due to the hormonal environment pertaining during early lactation, the ability of an animal to meet this increased demand through an increase in intake depends on both the protein and energy content of the diet. Should the nutrient balance provided from absorbed nutrients be such that constraints on energy intake limit protein intake, then endogenous protein is mobilized. The ability of endogenous protein to replace the dietary supply is limited by both the amount available and also by the further reduction in intake caused through increased brain histamine levels. This appears to be a general response to loss of body protein and, whilst the benefits of such a response are clear in non-pregnant, non-lactating animals, it is less clear what purpose this mechanism serves during lactation. Further studies are necessary to investigate this, but it may be that a further reduction in intake serves to increase the rate of body fat loss. Once body fat levels have been depleted, part of the metabolic embarrassment caused by over-supply of energy will be relieved, allowing higher intakes.

\section{REFERENCES}

Allison, J. B. \& Wannemacher, R. W. (1965). The concept and significance of labile and over-all protein reserves of the body. American Journal of Clinical Nutrition 16, 445-452. 
Blaxter, K. L. (1989). Energy Metabolism in Animals and Man, p. 235. Cambridge: Cambridge University Press. Botts, R. L., Hemken, R. W. \& Bull, L. S. (1979). Protein reserves in the lactating dairy cow. Journal of Dairy Science 62, 433-440.

Butts, C. A., Moughan, P. J., Smith, W. C., Reynolds, G. W. \& Garrick, D. J. (1993). The effect of food dry matter intake on endogenous ileal amino acid excretion determined under peptide alimentation in the $50 \mathrm{~kg}$ liveweight pig. Journal of the Science of Food and Agriculture 62, 235-243.

Emmans, G. C. \& Oldham, J. D. (1988). Modelling of growth and nutrition in different species. In Modelling of Livestock Production Systems, pp. 13-21 [S. Korver and J. A. M. Van Arendonk, editors]. Wageningen: Kluwer Academic Publishers.

Friggens, N.C., Hay, D. E. F. \& Oldham, J. D. (1993). Interactions between major nutrients in the diet and the lactational performance of rats. British Journal of Nutrition 69, 59-71.

Girard, J., Burnol, A.-F., Leturque, A. \& Ferre, P. (1987). Glucose homeostasis in pregnancy and lactation. Biochemical Society Transactions 15, 1028-1030.

Goodwill, M., Jessop, N. S. \& Oldham, J. D. (1996a). Mammary sensitivity to protein restriction and realimentation. British Journal of Nutrition 76, 423-434.

Goodwill, M., Jessop, N. S. \& Oldham, J. D. (1996b). Does the histamine receptor antagonist, cyproheptadine, increase voluntary food intake? Proceedings of the Nutrition Society 55, 252A.

Jessop, N. S. (1996). Protein energy interactions and their influence on lactational performance. Journal of Dairy Science 79, Suppl. 1, 76.

Knight, C. H. \& Peaker, M. (1982). Development of the mammary gland. Journal of Reproduction and Fertility 65, 521-536.

Kyriazakis, I., Emmans, G. C. \& Whittemore, C. T. (1990). Diet selection in pigs: choices made by growing pigs given foods of different protein concentration. Animal Production 51, 189-199.

Marinchenko, G. V., McNamara, J. P., Becker-Khaleel, B. \& Parmley, K. (1992). Growth hormone alters metabolic effects and proteolysis of insulin in adipose tissue during lactation. Proceedings of the Society of Experimental Biology and Medicine 200, 657-666.

Mercer, L. P., Dodds, S. J., Schweisthal, M. R. \& Dunn, J. D. (1989). Brain histidine and food intake in rats fed diets deficient in single amino acids. Journal of Nutrition 119, 66-94.

Mercer, L. P., Kelly, D. S., Humphries, L. L. \& Dunn, J. D. (1994). Manipulation of central nervous system histamine or histaminergic receptors $\left(\mathrm{H}_{1}\right)$ affects food intake in rats. Journal of Nutrition 124, 1029-1036.

Motil, K. J., Thotathuchery, M., Montandon, C. M., Hachey, D. L., Boutton, T. W., Klein, P. D. \& Garza, C. (1994). Insulin, cortisol and thyroid hormones modulate maternal protein status and milk production and composition in humans. Journal of Nutrition 124, 1248-1257.

Moughan, P. J. (1989). Simulation of the daily partitioning of lysine in the $50 \mathrm{~kg}$ liveweight pig - a factorial approach to estimating amino acid requirements for growth and maintenance. Research and Development in Agriculture 6, 7-14.

Naismith, D. J. \& Morgan, B. L. G. (1976). The biphasic nature of protein metabolism during pregnancy in the rat. British Journal of Nutrition 36, 563-566.

Oldham, J. D. (1987). Efficiencies of amino acid utilisation. In Feed Evaluation and Protein Requirement Systems for Ruminants, pp. 171-186 [R. Jarrige and G. Alderman, editors]. Luxembourg: Commission of the European Communities.

Pine, A. P., Jessop, N. S. \& Oldham, J. D. (1994a). Maternal protein reserves and their influence on lactational performance in rats. British Journal of Nutrition 71, 13-27.

Pine, A. P., Jessop, N. S., Allan, G. F. \& Oldham, J. D. (1994b). Maternal protein reserves and their influence on lactational performance in rats 2. Effects of dietary protein restriction during gestation and lactation on tissue protein metabolism and $\mathrm{Na}^{+}, \mathrm{K}^{+}$-ATPase (EC 3.6.1.3) activity. British Journal of Nutrition 72, 181-197.

Pine, A. P., Jessop, N. S., Allan, G. F. \& Oldham, J. D. (1994c). Maternal protein reserves and their influence on lactational performance in rats 4 . Tissue protein synthesis and turnover associated with mobilization of maternal protein. British Journal of Nutrition 72, 831-844. 